1 Title: Mild cognitive impairment is associated with skeletal muscle mitochondrial deficits

2 Authors. Morris, Jill K*., ${ }^{1,4}$ McCoin, Colin S., ${ }^{1,2}$ Fuller, Kelly N., ${ }^{1,2}$ John, Casey S., ${ }^{1,4}$ Wilkins, 3 Heather M., ${ }^{1,4}$ Wang, Xiaowan, ${ }^{1,4}$ Sharma, Palash, ${ }^{3}$ Burns, Jeffrey M., ${ }^{1,4}$ Vidoni, Eric D., ${ }^{1,4}$

4 Mahnken, Jonathan D., ${ }^{3,4}$ Swerdlow, Russell H., ${ }^{1,4}$ and John P. Thyfault ${ }^{\star 1,2}$

\title{
Affiliations
}

${ }^{1}$ Department of Neurology, University of Kansas Medical Center

${ }^{2}$ Department of Molecular and Integrative Physiology, University of Kansas Medical Center

${ }^{3}$ Department of Biostatistics, University of Kansas Medical Center

$10{ }^{4}$ University of Kansas Alzheimer's Disease Center

\section{$12{ }^{*}$ Co-Corresponding authors}

13 Jill K. Morris

14 Assistant Professor, Department of Neurology

15 University of Kansas Medical Center

16 Kansas City, KS,

17 913-945-7675

18 jmorris2@kumc.edu

John P. Thyfault

21 Professor, Department of Molecular and Integrative Physiology

22 University of Kansas Medical Center

23 913-588-1790

24 jthyfault@kumc.edu

25

\section{Conflict of interest statement}

27 The authors have declared that no conflict of interest exists. 
medRxiv preprint doi: https://doi.org/10.1101/2020.07.20.20158022; this version posted July 25, 2020. The copyright holder for this preprint (which was not certified by peer review) is the author/funder, who has granted medRxiv a license to display the preprint in perpetuity.

All rights reserved. No reuse allowed without permission.

\section{Abstract}

Alzheimer's Disease (AD) is associated with insulin resistance and low cardiorespiratory fitness, suggestive of impaired skeletal muscle mitochondrial function. We examined if individuals with Mild Cognitive Impairment (MCI), the earliest phase of AD-related cognitive decline, exhibit reduced skeletal muscle mitochondrial function, and if AD medication impacted outcomes. We present data from 50 individuals, including cognitively healthy older adults $(\mathrm{CH}$; $n=24) 60+$ years of age and clinically diagnosed $M C l$ subjects $(n=26) . M C l$ subjects were subdivided into two groups; no $A D$ medication ( $\mathrm{MCl} ; \mathrm{n}=11)$, or $\mathrm{AD}$ medication treated $(\mathrm{MCl}+\mathrm{med}$; $\mathrm{n}=15$ ). A skeletal muscle biopsy (vastus lateralis) was obtained and mitochondrial respiratory kinetics was measured in permeabilized muscle fibers. MCI subjects exhibited lower lipidstimulated skeletal muscle mitochondrial respiration (State 3, ADP-stimulated) than both $\mathrm{CH}$ individuals $(p=0.043)$ and medication-treated $\mathrm{MCl}$ subjects $(\mathrm{p}=0.006) . \mathrm{MCl}$ also exhibited poorer mitochondrial coupling control compared to $\mathrm{CH}$ subjects $(\mathrm{p}=0.014)$, while $\mathrm{MCl}+$ med and $\mathrm{CH}$ subjects did not differ. Compared to $\mathrm{CH}$ individuals, skeletal muscle mitochondrial leak control ratio was lower for the $\mathrm{MCl}+$ med group $(\mathrm{p}=0.008)$ and trended lower for non-medicated $\mathrm{MCl}$ $(p=0.06)$, which suggests greater mitochondrial uncoupling in $\mathrm{MCl}$. Skeletal muscle mitochondrial respiration is impaired in untreated $\mathrm{MCl}$ but normalized in medication-treated $\mathrm{MCl}$ participants while mitochondrial leak control is impaired regardless of medication status. These results provide further evidence that systemic mitochondrial deficits occur in the very early

47 stages of $A D$, and that mitochondrial function is partially influenced by $A D$ medication. Further analysis for a role of muscle mitochondria in the progression of early $A D$ is warranted. 
medRxiv preprint doi: https://doi.org/10.1101/2020.07.20.20158022; this version posted July 25, 2020. The copyright holder for this preprint (which was not certified by peer review) is the author/funder, who has granted medRxiv a license to display the preprint in perpetuity.

All rights reserved. No reuse allowed without permission.

\section{Introduction}

Emerging evidence suggests that changes in energy metabolism may play a role in the development and progression of Alzheimer's Disease (AD). Results show that mitochondrial function is compromised systemically in $A D$, in tissues ranging from skeletal muscle to brain, ${ }^{1}$ and we have shown that AD subjects have both reduced aerobic capacity ${ }^{2}$ and reduced insulin sensitivity $^{3}$ compared to cognitively healthy older adults. There is also evidence that mitochondrial dysfunction in skeletal muscle is a cause of whole body insulin resistance,${ }^{4-6} \mathrm{a}$ recognized risk factor for $A D \cdot{ }^{7-20}$ Moreover, skeletal muscle mitochondrial content and functional capacity plays a key role in maximal exercise capacity and cardiorespiratory fitness. However, skeletal muscle mitochondrial function has never been directly assessed in cognitively impaired individuals. Given that skeletal muscle tissue comprises $30-40 \%$ of body mass and declines with aging, ${ }^{21}$ metabolic deficits in this tissue have a profound impact on systemic metabolism and the development of age-related chronic disease states.

The overall goal of this study was to test the hypothesis that individuals in the earliest stage of $A D$-related cognitive decline, Mild Cognitive Impairment (MCI), possess reduced mitochondrial function and specifically, reduced State 3 (ADP-stimulated) skeletal muscle mitochondrial respiratory capacity compared to cognitively healthy elderly adults $(\mathrm{CH})$. We also postulated that differences in respiratory capacity could be driven by AD genetic risk (Apolipoprotein $\varepsilon 4 ;$ APOE4)) or non-genetic risk (overweight/obesity or physical activity). However, emerging literature also suggests that $A D$ medications influence mitochondrial function. Because over half (58\%) of $\mathrm{MCl}$ subjects in our study were actively using $\mathrm{AD}$ medication, we also characterized skeletal muscle mitochondrial effects in the presence and absence of medication treatment. Our results show a clear effect of $\mathrm{MCl}$ status being linked to compromised mitochondrial function in skeletal muscle that is partially modified by medication status. 
medRxiv preprint doi: https://doi.org/10.1101/2020.07.20.20158022; this version posted July 25, 2020. The copyright holder for this preprint (which was not certified by peer review) is the author/funder, who has granted medRxiv a license to display the preprint in perpetuity.

\section{Methods}

\section{Ethical approval and recruitment}

This study was approved by the University of Kansas Medical Center's Institutional Review Board (IRB \# 140787). All participants in this study provided informed consent according to institutional guidelines and in accordance with the Declaration of Helsinki. Participants were recruited by the KU Alzheimer's Disease Center (KU ADC) recruitment division as previously described. ${ }^{57} 180$ qualifying individuals were pre-screened for this study by the KU ADC recruitment operations team. 58 individuals were selected for additional in-depth screening by the study coordinator, with 52 participants enrolled in the study. One individual was withdrawn from the study prior to the muscle biopsy due to safety labs out of range and one individual was excluded from analysis due to the muscle sample being compromised prior to analysis. We thus report results from 50 participants.

All individuals were over 60 years of age and on stable medication doses for at least 30 days. Diagnostic inclusion criteria included no prior memory complaints ( $\mathrm{CH}$ older adults), or $\mathrm{MCI}$ diagnosed by a clinician and verified with medical records. Individuals were excluded from participating if they had moderate or severe $A D$, other neurological disorders that could impair cognition, evidence of bleeding disorders during screening (elevated PT/PTT values), prior bleeding problems or use of anti-platelet medication, Warfarin, or any other anticoagulant, clinically significant disease, clinically significant psychiatric disorder, systemic illness or infection likely to affect safety, clinically-evident stroke, myocardial infarction or coronary artery disease in the last 2 years, insulin dependent diabetes, or significant pain or musculoskeletal symptoms that would affect safety. One individual in the $\mathrm{CH}$ group had a diagnosis of Type 2 Diabetes but was not using diabetic medication. Interested participants completed a brief phone screen to verify safety to complete visits. Participants that appeared eligible were scheduled an in-person visit. A screening blood panel was also performed prior to the muscle biopsy to verify that no blooding disorders were present. 
medRxiv preprint doi: https://doi.org/10.1101/2020.07.20.20158022; this version posted July 25, 2020. The copyright holder for this preprint (which was not certified by peer review) is the author/funder, who has granted medRxiv a license to display the preprint in perpetuity.

All rights reserved. No reuse allowed without permission.

101

102

103

104

105

106

107

108

109

110

111

112

113

114

115

116

117

118

119

120

121

122

123

124

125

126

Individuals completed 2 study visits: Visit 1 (Graded exercise test; GXT, and dual energy x-ray absorptiometry (DXA) scan), and Visit 2 (fasting blood draw, muscle biopsy).

\section{Medications}

Medication use was verified by medical record. All individuals in the study were required to be on stable medication doses for greater than 30 days prior to enrollment. Fifteen $\mathrm{MCl}$ subjects $(58 \%$ of study subjects with $\mathrm{MCl}$ ) were routinely taking medication for mild memory complaints. All 15 of these individuals were using the cholinesterase inhibitor donepezil ( $10 \mathrm{mg} /$ day; 12 or $5 \mathrm{mg} /$ day; 3 , due to inability to tolerate a $10 \mathrm{mg} /$ day dose). Of these 15 subjects, 5 individuals were also taking memantine, an NMDA receptor antagonist (5$28 \mathrm{mg} /$ day).

\section{Anthropometric measures}

Individuals reported to the KU Clinical and Translational Research Unit (CTSU) for Visit 1 following an overnight fast. After a 5 minute rest period, vital signs were obtained. We measured height in $\mathrm{cm}$ and total body mass using a digital scale accurate to $0.1 \mathrm{~kg}$ (Seca Platform Scale, model 707). Waist and hip circumference were also measured. Subjects were asked to void and evaluated using a DXA scan (Lunar Prodigy, version 11.2068) to determine lean mass, fat mass, and bone mineral density.

\section{Cardiorespiratory fitness testing.}

A GXT was performed according to a modified Bruce protocol on a treadmill as previously described to determine cardiorespiratory fitness. ${ }^{58}$ Subjects were attached to a 12 lead electrocardiograph to monitor cardiac rhythm, and a non-rebreathing mask to continuously capture oxygen and carbon dioxide for 3 minutes while seated and relaxed at rest. This allowed for calculation of a resting Respiratory Exchange Ratio (RER). To begin the test, each participant mounted a treadmill and began walking with speed and incline gradually increasing with each 2 minute stage as previously reported. ${ }^{59}$ Blood pressure and rating of perceived exertion were collected at the end of each stage. The test was terminated if the participant 
medRxiv preprint doi: https://doi.org/10.1101/2020.07.20.20158022; this version posted July 25, 2020. The copyright holder for this preprint (which was not certified by peer review) is the author/funder, who has granted medRxiv a license to display the preprint in perpetuity.

All rights reserved. No reuse allowed without permission.

reached volitional fatigue or met the absolute test termination criteria ( $R E R>=1.1, R P E 17$, plateau in $\mathrm{VO}_{2} / 100 \mathrm{ml}$ change, $90 \% \mathrm{HRmax}$ ). Maximal oxygen uptake during the GXT was calculated relative to whole body mass $(\mathrm{mL} / \mathrm{kg} / \mathrm{min})$. Our group has previously validated $\mathrm{VO}_{2}$ peak testing in both $\mathrm{AD}$ subjects and in $\mathrm{CH}$ older adults. ${ }^{58,60,61}$

\section{Accelerometry}

At Visit 1, individuals were given a wrist-worn Actigraph GT9X watch (Sample Rate $30 \mathrm{~Hz}$ ) and asked to wear the watch for 7 days to capture both weekday and weekend physical activity and sedentary behavior patterns. Accelerometers were returned to the study team during Visit 2 for data analysis. Wear validation was performed using a computer algorithm ${ }^{62}$ with a minimum of 600 mins wear time per day and 4 valid days required for inclusion of data. No individuals were excluded from analysis due to inadequate wear time. 1 subject was excluded from the analyses due to corrupt data. Analyses were performed using Actigraph ActiLife 6 software (v6.13.3).

\section{Blood biomarkers.}

Approximately 2 weeks following Visit 1 , subjects returned to the KU Clinical Translational Science Unit (CTSU) for visit 2 following an overnight fast. Blood samples were analyzed using a lipid panel (Quest Diagnostics) to determine cholesterol HDL, LDL, LDL/HDL, and triglyceride values. Blood was collected into serum separator tubes and processed to generate serum, which was frozen at $-80^{\circ} \mathrm{C}$ until further analysis. Serum glucose was measured using a colormetric assay (Sigma-Aldrich) and insulin was measured using ELISA (Alpco Diagnostics).

\section{Muscle biopsy and mitochondrial respirometry analyses}

Following the visit 2 blood draw, a skeletal muscle biopsy of the vastus lateralis $(\sim 120$ mg tissue) was performed. Freshly obtained muscle tissue was immediately dissected free of connective tissue and separated into segments, with a portion $(\sim 30 \mathrm{mg})$ placed into ice cold buffer X (50 mM K-MES, 7.23 mM K 2 EGTA, 2.77 mM CaK 2 EGTA, 20 mM Imidazole, 20 mM Taurine, 
medRxiv preprint doi: https://doi.org/10.1101/2020.07.20.20158022; this version posted July 25, 2020. The copyright holder for this preprint (which was not certified by peer review) is the author/funder, who has granted medRxiv a license to display the preprint in perpetuity.

All rights reserved. No reuse allowed without permission.

5.7 mM Na-ATP, $14.3 \mathrm{mM} \mathrm{Na-PCr,} 6.56 \mathrm{mM} \mathrm{MgCl}_{2}-6 \mathrm{H}_{2} \mathrm{O} ; \mathrm{pH}$ 7.1) for transport to the laboratory and analysis of respiratory kinetics.

We measured basal and ADP-stimulated respiratory kinetics utilizing lipid substrates in duplicate on permeabilized fiber bundles in an Oroboros Oxygraph-2k system (Innsbruck, Austria). All mitochondrial analyses were completed in real time within 2-3 hours of the biopsy. Multiple small fiber bundles were teased from the $\sim 30 \mathrm{mg}$ muscle sample on ice using fine forceps under a dissecting scope in ice cold buffer X. Following fiber bundle preparation, bundles were placed into buffer $X$ containing $30 \mathrm{ug} / \mathrm{mL}$ saponin for 30 minutes on a rotator at $4^{\circ} \mathrm{C}$, prior to washing with ice cold Buffer Z (105 mM K-MES, $30 \mathrm{mM} \mathrm{KCl,} 10 \mathrm{mM} \mathrm{K}_{2} \mathrm{HPO}_{4}, 5 \mathrm{mM} \mathrm{MgCl} \mathrm{M}_{2}-6 \mathrm{H}_{2} \mathrm{O}$ and $0.5 \% \mathrm{w} / \mathrm{w}$ fatty acid-free BSA; $\mathrm{pH} 7.1)+0.5 \mathrm{M}$ EGTA.

We used high resolution respirometry to assess $\mathrm{O}_{2}$ consumption rate within prepared muscle fiber bundles. Analyses were performed at $37^{\circ} \mathrm{C}$ in Buffer $\mathrm{Z}$ with $0.5 \mathrm{M}$ EGTA and $20 \mathrm{mM}$ creatine monohydrate. Basal respiratory kinetics were obtained in the presence of $0.01 \mathrm{mM}$ blebbistatin, $0.02 \mathrm{mM}$ palmitoyl CoA, $0.5 \mathrm{mM}$ malate, $5 \mathrm{mM}$ carnitine, and $0.018 \mathrm{mM}$ palmitoylcarnitine. $\mathrm{O}_{2}$ was added to the chamber for an initial concentration of $\sim 260 \mu \mathrm{M}$. After reaching steady state, this was followed by sequential addition of $4 \mathrm{mM}$ ADP to assess State 3 respiration through Complex I, and $10 \mathrm{mM}$ succinate (Complex II substrate; State 3S). We assessed uncoupled respiration by adding carbonylcyanide-p-trifluoromethoxyphenylhydrazone (FCCP, a protonophoric uncoupler) until we observed maximal respiration. Following analyses, fibers were freeze dried overnight in a lyophilizer (FreeZone 2.5L, Labconco, Kansas City, MO) and weighed using a microbalance (MX5, Mettler Toledo, Columbus, OH). Mitochondrial respiration values were normalized to dry muscle weight and are expressed as $\mathrm{pmol} \cdot \mathrm{s}^{-1} \cdot \mathrm{mg}^{-1} \mathrm{dry}$ weight. We calculated coupling control ratio by dividing leak respiration by phosphorylating State 3 respiration (ADP condition; L/P). We calculated leak control ratio by dividing leak respiration by FCCP stimulated respiration (L/E).

\section{Protein expression analyses.}


medRxiv preprint doi: https://doi.org/10.1101/2020.07.20.20158022; this version posted July 25, 2020. The copyright holder for this preprint (which was not certified by peer review) is the author/funder, who has granted medRxiv a license to display the preprint in perpetuity.

All rights reserved. No reuse allowed without permission.

Frozen muscle was powdered and weighed prior to processing with a TissueLyser II bead homogenizer (Qiagen, Germantown, MD) in buffer containing 50 mM HEPES, 12 mM sodium pyrophosphate, $100 \mathrm{mM} \mathrm{NaF}, 10 \mathrm{mM}$ EDTA, $400 \mu \mathrm{L}$ each phosphatase inhibitor cocktail 2 and 3 (Sigma-Aldrich, St. Louis, MO), and 1\% Triton X-100. Protein concentration assessed using a Pierce BCA assay (Thermo Scientific, Rockford, IL) and samples prepared for western blotting prior to separation using SDS-PAGE. Proteins were transferred to PVDF membrane prior incubation with Total OXPHOS primary antibody (Abcam, Cambridge, MA). Densitometry was measured using ImageLab 5.2.1 (BioRad, Hercules, CA) and protein loading corrected using $0.1 \%$ amido-black (Sigma-Aldrich).

\section{Statistical Analyses}

Group differences for continuous variables were assessed using ordinary least squares regression to perform ANOVA-like analyses with adjustment for other factors. Significant findings were further explored using LSD post-hoc analyses. For an overall assessment of mitochondrial response under multiple substrate conditions, we used linear mixed modeling to account for repeated measures. Model assessment included residual analysis. Linear mixed model results assuming the normal distribution were violated with respect to the constant variance assumption. Log-transformation did not correct this problem with the residuals. We

196 thus adjusted to use a generalized linear mixed model assuming an underlying Poisson

197 distribution as this allowed for the variance to increase as a function of the mean, and this

198 resolved the poor diagnostic indications from the linear mixed models. The relationship between

199 CRF and our primary mitochondrial outcome measure of State 3 (ADP) flux was explored using

200 linear regression. All analyses were adjusted for age, sex, APOE4 carrier status, and 
medRxiv preprint doi: https://doi.org/10.1101/2020.07.20.20158022; this version posted July 25, 2020. The copyright holder for this preprint (which was not certified by peer review) is the author/funder, who has granted medRxiv a license to display the preprint in perpetuity.

204

205

206

207

208

209

210

211

212

213

214

215

216

217

218

219

220

221

222

223

224

225

226

227

228

229

\section{Results.}

\section{Subject Characteristics.}

$\mathrm{CH}, \mathrm{MCl}$, and $\mathrm{MCl}+$ med groups did not significantly differ by age, sex, genotype (APOE4 carrier status) or overweight/obesity status (Table 1). Within the $\mathrm{MCl}+$ med group, all participants $(n=15,100 \%)$ were using the AD medication donepezil, an acetylcholinesterase inhibitor. Of those subjects, 33\% $(n=5)$ were also using the AD medication memantine. There was no difference in years of education between groups. Scores for the Mini-Mental State Examination (MMSE) were available for all MCI subjects. MMSE scores were not different between $\mathrm{MCl}$ and $\mathrm{MCl}+$ med groups (mean MMSE score 26 for each group), and these scores are within the range commonly observed in $\mathrm{MCl}$ populations. ${ }^{22}$

\section{Mitochondrial respiration.}

To test mitochondrial function, we measured respiratory kinetics in permeabilized skeletal muscle fiber bundles. Analysis of our primary outcome measure, the respiratory response to ADP, was different between groups. We observed differences in ADP-stimulated (State 3) respiratory kinetics ( $p=0.020$; Figure 1A), with $\mathrm{MCl}$ subjects exhibiting lower mitochondrial respiration than $\mathrm{CH}(\mathrm{p}=0.043)$ and $\mathrm{MCl}+\mathrm{Med}(\mathrm{p}=0.006)$ individuals. We also performed multiple additional titrations of substrates, including Succinate (State 3S) and FCCP (uncoupled respiration) to assess respiratory control under a sequence of conditions. In our analysis accounting for these repeated measures across all sequence conditions, we also found the relationship between groups differed across the sequence of conditions $(p<0.001)$. Within condition difference between groups were detected in this repeated measures analysis for the ADP-stimulated (State 3) condition ( $p=0.005$ ), and for Basal, Succinate (State 3S), and FCCP group comparison tests resulted in $p=0.067, p=0.254$, and $p=0.073$, respectively (Figure $1 B$ ). In this repeated measures analysis, within the ADP-stimulated condition $\mathrm{MCl}$ subjects again indicated lower mitochondrial respiration than $\mathrm{CH}(\mathrm{p}=0.016)$ and $\mathrm{MCl}+\mathrm{Med}(\mathrm{p}=0.001)$ individuals. 
medRxiv preprint doi: https://doi.org/10.1101/2020.07.20.20158022; this version posted July 25, 2020. The copyright holder for this preprint (which was not certified by peer review) is the author/funder, who has granted medRxiv a license to display the preprint in perpetuity.

Coupling control ratio provides information on the coupling of electron flux through the electron transport chain to ATP production (lower values equal higher coupling). Coupling control ratio was significantly different between groups $(\mathrm{p}=0.045$; Figure $2 \mathrm{~A}) . \mathrm{MCl}$ subjects exhibited poorer coupling control compared to $\mathrm{CH}$ subjects $(\mathrm{p}=0.014)$, while $\mathrm{MCl}+$ med and $\mathrm{CH}$ subjects did not differ. Similarly, leak control ratio, which can be used to assess uncoupling during constant electron transport flow was also different between groups ( $p=0.019$; Figure 2B). Leak control ratio was impaired in the $\mathrm{MCl}+$ med group compared to $\mathrm{CH}$ subjects $(\mathrm{p}=0.008)$ with a trend for a difference in $\mathrm{MCl}$ vs. $\mathrm{CH}(\mathrm{p}=0.06)$, suggesting greater uncoupling of the system in $\mathrm{MCI}$ regardless of medication status.

\section{Anthropometric characteristics, physical activity and fitness}

All groups were highly active (>10,000 activity counts per day), but differed in physical activity $(p=0.010)$, with $\mathrm{MCl}+$ med subjects exhibiting slightly lower activity counts compared to both $\mathrm{CH}(p=0.008)$ and $\mathrm{MCl}$ subjects $(\mathrm{p}=0.009)$. This did not translate into fitness differences; all participants completed a graded cardiorespiratory exercise text (GXT) and overall fitness levels

$246\left(\mathrm{VO}_{2 \text { peak }}\right)$ were not different between groups. However, the duration of the GXT differed significantly $(\mathrm{p}<0.001)$ with a shorter test duration observed in $\mathrm{MCl}+$ med subjects compared to both $\mathrm{CH}$ and $\mathrm{MCl}$ subjects (CN vs. $\mathrm{MCl}, \mathrm{p}<0.001, \mathrm{MCl}$ vs. $\mathrm{MCl}+$ med, $\mathrm{p}=0.012)$. RER was measured in the fasted, rested condition prior to the GXT to assess substrate utilization patterns. Resting RER differed between groups $(p=0.031)$, with lower RER in $\mathrm{MCl}(p=0.023)$

251 and $\mathrm{MCl}+$ med subjects $(\mathrm{p}=0.044)$, suggesting potential differences in resting substrate

252 metabolism. We also observed differences in fat mass $(p=0.027)$, with $\mathrm{MCl}$ individuals exhibiting

253 less fat mass than $\mathrm{MCl}+$ med subjects $(\mathrm{p}=0.007)$ and marginally lower fat mass compared to $\mathrm{CH}$ 254 individuals $(p=0.060)$. Lean mass and bone mineral density were not different amongst groups 255 (Table 1). 
medRxiv preprint doi: https://doi.org/10.1101/2020.07.20.20158022; this version posted July 25, 2020. The copyright holder for this preprint (which was not certified by peer review) is the author/funder, who has granted medRxiv a license to display the preprint in perpetuity.

\section{Relationship between mitochondrial respiration and fitness}

Given the observed group differences in State 3 (ADP) respiration, we examined the linear relationship between State 3 respiration and cardiorespiratory fitness to determine if mitochondrial function is related to cross-sectional cardiorespiratory fitness levels. When we examined only individuals who met American College of Sports Medicine (ACSM) criteria for a reliable maximal exercise test $\left(\mathrm{VO}_{2 \max }, \mathrm{n}=44\right.$ subjects) we observed a positive linear relationship between $\mathrm{VO}_{2 \max }$ and State $3(\mathrm{ADP})$ skeletal muscle respiration in both $\mathrm{CH}$ subjects $(\beta=0.615$, $\mathrm{p}=0.024$ ) and $\mathrm{MCl}$ individuals $(\beta=0.615, \mathrm{p}=0.036$; Figure 3$)$. There was no significant relationship between $\mathrm{VO}_{2 m a x}$ and skeletal muscle respiration in medication-treated $\mathrm{MCl}$ participants, suggesting a potential dyscoupling of mitochondrial function and fitness in those individuals. We did not observe a significant relationship within the cohort as a whole or within $\mathrm{VO}_{2 \text { peak }}$ when including all participants regardless of ACSM criteria, indicating that the exercise test quality is an important factor when investigating these relationships.

\section{Protein expression of the electron transport system}

We assessed protein expression the electron transport system in a subset of participants with sufficient available skeletal muscle samples $(n=44)$. Although complex expression showed the same trends observed for the functional outcomes, these were not significantly different between groups (Figure 4).

\section{Blood biomarkers}

We did not observe group differences for plasma cholesterol, triglycerides, Low Density Lipoprotein (LDL), High Density Lipoprotein (HDL), glucose, or insulin (Table 2). LDL/HDL ratio 
medRxiv preprint doi: https://doi.org/10.1101/2020.07.20.20158022; this version posted July 25, 2020. The copyright holder for this preprint (which was not certified by peer review) is the author/funder, who has granted medRxiv a license to display the preprint in perpetuity.

All rights reserved. No reuse allowed without permission.

281 and homeostatic model assessment of insulin resistance (HOMA-IR) did not differ between

282 groups.

283 Adverse events.

There were 6 adverse events possibly or definitely related to the GXT or muscle biopsy:

2852 mild, and 4 moderate in severity. Mild adverse events possibly or probably related to the

286 intervention included abnormal screening labs (1) and prolonged muscle soreness after the

287 muscle biopsy (1). Moderate severity adverse events included heart rhythm abnormalities

288 during fitness testing (3) and fainting after muscle biopsy (1).

289

290 
medRxiv preprint doi: https://doi.org/10.1101/2020.07.20.20158022; this version posted July 25, 2020. The copyright holder for this preprint (which was not certified by peer review) is the author/funder, who has granted medRxiv a license to display the preprint in perpetuity.

All rights reserved. No reuse allowed without permission.

\section{Discussion.}

We report here the first ex-vivo assessment of skeletal muscle mitochondrial function in $\mathrm{MCl}$, the earliest clinical stage of $\mathrm{AD}$. Our primary finding is that unmedicated $\mathrm{MCl}$ participants display reduced skeletal muscle mitochondrial respiratory capacity (Figure 1) and poorer coupling control (Figure 2) compared to $\mathrm{CH}$ older adults. This suggests that prior findings of reduced insulin sensitivity and cardiorespiratory fitness in $A D^{2,3}$ may be partly driven by deficits in skeletal muscle mitochondrial function. Moreover, $\mathrm{MCl}$ subjects treated with $\mathrm{AD}$ medication (primarily acetylcholinesterase inhibitors) displayed mitochondrial respiration values in line with $\mathrm{CH}$ subjects. Our results thus also suggest that a less-recognized mechanism of medicationrelated benefit may be improved mitochondrial function in systemic metabolic tissues and the brain. However, future prospective (pre- and post-treatment) studies are necessary to confirm that a commonly used AD medication can indeed impact skeletal muscle mitochondrial dysfunction in $\mathrm{MCl}$.

There is growing evidence for bioenergetic deficits in AD. Cerebral hypometabolism, a marker of reduced energy metabolism, is an early AD biomarker ${ }^{23,24}$ and occurs first in highly metabolic brain regions ${ }^{25,26}$. While bulk of energy in the brain is derived via oxidative phosphorylation in mitochondria, it remains difficult to assess cerebral mitochondrial function directly. However, there is evidence mitochondrial function may be compromised systemically in early $A D^{1,27,28}$. It has also been shown that reactive oxygen species produced in mitochondria enhance $A \beta$ production, which can deposit within mitochondria resulting in further deficits ${ }^{28,29}$. Preclinical work further suggests mitochondrial deficits in AD models. Mice transgenic for human APOE4 display mitochondrial dysfunction in neurons, ${ }^{30}$ and both the double and triple transgenic AD mouse models ${ }^{31,32}$ display marked mitochondrial dysfunction in skeletal muscle ${ }^{32,33}$. Our findings of a deficit in mitochondrial respiration in $\mathrm{MCl}$ compared to cognitively healthy older adults support a growing body of evidence implicating bioenergetic dysfunction and 
medRxiv preprint doi: https://doi.org/10.1101/2020.07.20.20158022; this version posted July 25, 2020. The copyright holder for this preprint (which was not certified by peer review) is the author/funder, who has granted medRxiv a license to display the preprint in perpetuity.

All rights reserved. No reuse allowed without permission.

cognitive decline. To our knowledge this is the first study to directly characterize an ex vivo skeletal muscle mitochondrial function deficit in $\mathrm{MCl}$.

Preclinical evidence also supports our observations of recovered mitochondrial function in medication treated $\mathrm{MCl}$ subjects. In our study, all 15 subjects in the $\mathrm{MCl}+$ med group were receiving the cholinesterase inhibitor donepezil. In transgenic AD mice, donepezil treatment ameliorates cognitive deficits prior to acetylcholinesterase inhibition and decreases accumulation of $A \beta$ in brain mitochondria. ${ }^{34}$ Pre-treatment of rat brain mitochondria with donepezil also decreases mitochondrial accumulation after oligomeric $A \beta$ exposure and mitigates $A \beta$-related decline in ATP production, further suggesting protection against A $\beta$ induced deficits. ${ }^{34}$ Donepezil has also shown anti-amnestic effects and protection against A $\beta$ induced neurodegeneration when both are administered intracerebroventricularly in mice. ${ }^{35}$ It is possible that some of the benefits of donepezil are mediated through the sigma 1 receptor, a chaperone protein that localizes to mitochondria associated endoplasmic reticulum membranes. ${ }^{36}$ This is of interest because endoplasmic reticulum-mitochondria communication is postulated to be a key factor in AD-related metabolic disturbances and impaired mitochondrial respiration. ${ }^{37}$ Donepezil treatment has further been shown to induce mitochondrial biogenesis in both primary cultures of mouse hippocampal neurons and in hippocampal tissue, an effect that has been linked to induction of AMP-activated protein kinase (AMPK) and peroxisome proliferator-activated receptor gamma coactivator 1-alpha (PGC1a). ${ }^{38}$ Finally, other cholinesterase inhibitors or simply enhancing cholinergic tone has shown direct benefits to mitochondria in cell studies, including improved mitochondrial function, decreased endoplasmic reticulum stress, and prevention of amyloid-beta induced apoptosis. ${ }^{39,40}$

It should be noted that the NMDA receptor antagonist memantine was concomitantly used with donepezil in $5 \mathrm{MCl}+$ med subjects. Memantine has also been shown to stimulate mitochondrial function ${ }^{41}$ and upregulate autophagy, enhancing clearance of damaged mitochondria from cultured neuronal cells. ${ }^{42}$ Thus it is likely that mitochondria-related effects in 
medRxiv preprint doi: https://doi.org/10.1101/2020.07.20.20158022; this version posted July 25, 2020. The copyright holder for this preprint (which was not certified by peer review) is the author/funder, who has granted medRxiv a license to display the preprint in perpetuity.

All rights reserved. No reuse allowed without permission.

response to $A D$ medication use may be of clinical relevance. In humans, the symptomatic benefits of donepezil have historically been attributed to effects on acetylcholine neurotransmission, ${ }^{43}$ and it remains debated as to whether cholinesterase inhibitors significantly modify the course of AD. Some degree of neuroprotection has been shown with donepezil, ${ }^{44,45}$ with donepezil treatment associated with slowed hippocampal atrophy. ${ }^{46}$ Moreover, a recent meta-analysis of over 40 randomized clinical trials involving cholinesterase inhibitors found a reduction in mortality, supporting a potential disease-modifying effect. ${ }^{47}$ Positive long term results have led investigators to suggest that cholinesterase inhibitors improve redox balance ${ }^{48}$ and oxidative capacity. ${ }^{49}$ This is supported by the main findings in our study, which show a decline in skeletal muscle mitochondrial respiratory capacity in unmedicated $\mathrm{MCl}$ subjects but not in the $\mathrm{MCl}+$ med group. The novelty in our findings is that medication treatment is associated with improved mitochondrial outcome measures in skeletal muscle. As already stated, a prospective study with donepezil treatment would be needed to determine if the drug truly rescues mitochondrial function in skeletal muscle. It will also be critical to determine if donepezil is working specifically on skeletal muscle or if is primarily improving neuronal/brain function and changes in muscle mitochondrial function are secondary. Despite the $\mathrm{MCl}+$ med group showing improved state 3 respiration, the group still showed reduced coupling and leak control ratio in line with $\mathrm{MCI}$ not taking medication. These impaired coupling values are likely due to increased rates of basal proton leak. Future work is needed to examine if altered uncoupling protein 1 or adenonine nucleotide transferase activites are driving increased basal proton leak. ${ }^{50}$

We then examined the relationship between cardiorespiratory fitness and ADPstimulated mitochondrial respiration in individuals who met established ACSM criteria for a maximal exercise test ${ }^{51}\left(\mathrm{VO}_{2 \max } ; \mathrm{n}=44\right)$. We observed a significant, positive linear relationship between cardiorespiratory fitness and ADP-stimulated mitochondrial respiration in both $\mathrm{CH}$ and $\mathrm{MCl}$ groups (Figure 3). This is consistent with prior work showing that skeletal muscle mitochondrial outcomes (content and function) are associated with whole-body exercise 
medRxiv preprint doi: https://doi.org/10.1101/2020.07.20.20158022; this version posted July 25, 2020. The copyright holder for this preprint (which was not certified by peer review) is the author/funder, who has granted medRxiv a license to display the preprint in perpetuity.

All rights reserved. No reuse allowed without permission.

368

capacity in cognitively healthy individuals throughout the lifespan. ${ }^{52-54}$ In contrast, there was no relationship between cardiorespiratory fitness and mitochondrial respiration within medication treated $\mathrm{MCl}$ subjects. This suggests that treatment may dyscouple the mitochondrial function and fitness relationship, although further work is needed to investigate this possibility. Interestingly, mitochondrial respiration was not related to cardiorespiratory fitness in any group when we did not use ACSM criteria for a valid exercise test $\left(\mathrm{VO}_{2 \text { peak }}\right.$ instead of $\left.\mathrm{VO}_{2 \max }\right)$ - an important consideration for studies examining the relationship between cellular respiration and whole-body fitness.

We anticipated that we would observe differences in skeletal muscle electron transport system protein expression between groups, as prior work suggests cytochrome oxidase deficits in $\mathrm{MCl}$ and $\mathrm{AD},{ }^{28,55}$ and a recent meta-analysis has shown complex IV deficits in $\mathrm{AD}$ brain. ${ }^{56}$ While we observed trends in the expected direction, these assessments did not reach significance, which could be due to our small sample size in the $\mathrm{MCl}$ group (Figure 4). Interestingly, we found that both unmedicated $\mathrm{MCl}$ and $\mathrm{MCl}+$ med subjects exhibited lower fasting RER values during quiet rest prior to the GXT. Both groups of $\mathrm{MCl}$ subjects appear to be more primed to use fatty acid substrates compared to cognitively healthy elderly adults, who exhibit an RER with a greater reliance on carbohydrate use. Somewhat surprisingly, we did not observe any differences in the lipid profile or fasting markers of insulin resistance between groups. This may be due to a variety of factors, including the early disease stage, the high degree of physical activity in all the subjects, the cross-sectional nature of the study, or other factors known to affect lipid homeostasis, such as genetics. Nevertheless, this indicates that the mitochondrial bioenergetic differences can exist outside of or even precede whole-body insulin resistance and/or dyslipidemia.

The primary strengths of this study were the robust ex vivo measures of mitochondrial respiration in skeletal muscle biopsy tissue, which is novel and has never been characterized in humans subjects with $\mathrm{MCl}$. However, muscle biopsies are somewhat invasive and our sample 
medRxiv preprint doi: https://doi.org/10.1101/2020.07.20.20158022; this version posted July 25, 2020. The copyright holder for this preprint (which was not certified by peer review) is the author/funder, who has granted medRxiv a license to display the preprint in perpetuity.

All rights reserved. No reuse allowed without permission.

394 size is limited. This limited our ability to parse out potential interaction relationships between

395 diagnostic, genetic, sex, and anthropometric characteristics, especially in terms of medication

396 use and dose. Future work should further investigate the effects of these important factors. In

397 addition, while we assessed mitochondrial function, we did not measure effects on other more

398 dynamic processes regulating mitochondrial quality control such as mitophagy or mitochondrial

399 fission/fusion. Finally, our study focused on $\mathrm{MCl}$ diagnosed in a clinical setting from community-

400 based providers. Additional work on $\mathrm{MCl}$ subjects with further characterization, such as

401 harmonized neuroimaging measures, is needed. Nonetheless, our clinically-relevant findings

402 suggest that there is mitochondrial defect in skeletal muscle associated with a disease that

403 occurs in the brain. Furthermore, it suggests a potential new mechanism by which donepezil

404 may impart benefit in early stage cognitive decline.

405

In conclusion, we show mitochondrial bioenergetic deficits occur in skeletal muscle, a

406 metabolic tissue that is critical for strength, movement, and metabolism particularly in aging,

407 during the earliest stages of AD-related cognitive decline. Moreover, these effects are likely

408 affected by the commonly used AD drug donepezil. Additional work to examine mechanisms by

409 which skeletal muscle mitochondrial dysfunction contributes to AD and how donepezil effects

410 these links is warranted.

411 
medRxiv preprint doi: https://doi.org/10.1101/2020.07.20.20158022; this version posted July 25, 2020. The copyright holder for this preprint (which was not certified by peer review) is the author/funder, who has granted medRxiv a license to display the preprint in perpetuity.

\section{Author contributions.}

413 Study design: J.K.M. and J.P.T.

414 Conducting experiments: C.S.M., K.N.F., H.M.W., X.W.

415 Acquiring data: J.K.M., C.S.M., K.N.F., C.S.J., H.M.W., X.W., E.DV.

416 Analyzing data: J.K.M, E.D.V., P.S., and J.D.M

417 Manuscript drafting: J.K.M, C.S.M., K.N.F., C.S.J., H.M.W., J.M.B., E.D.V., R.H.S., J.D.M., P.S. 418 and J.P.T.

419

420 Acknowledgements.

421 This project was supported by NIH R21AG056062-01 from the National Institute on Aging.

422 Other support for the authors includes R00AG050490 and R01AG062548 (JKM) R01KD121497

423 and R01AR071263 (JPT); TL1TR002368 (CSM); K-INBRE P20 GM103418 (JKM, JPT);

424 K99AG056600 (H.M.W), R21AG061548 (EVD), and P30AG035982. We would also like to thank 425 Dr. Chris Perry for technical assistance, and thank our research participants for their invaluable 426 contribution to this project.

427

428 
medRxiv preprint doi: https://doi.org/10.1101/2020.07.20.20158022; this version posted July 25, 2020. The copyright holder for this preprint (which was not certified by peer review) is the author/funder, who has granted medRxiv a license to display the preprint in perpetuity.

All rights reserved. No reuse allowed without permission.

\section{References}

$430 \quad 1 . \quad$ Wilkins HM, Morris JK. New Therapeutics to Modulate Mitochondrial Function in

$431 \quad$ Neurodegenerative Disorders. Current pharmaceutical design. 2017;23(5):731-752.

432 2. Vidoni ED, Honea RA, Billinger SA, Swerdlow RH, Burns JM. Cardiorespiratory fitness is

433 associated with atrophy in Alzheimer's and aging over 2 years. Neurobiol Aging.

434

435 2012;33(8):1624-1632.

3. Morris JK, Vidoni ED, Mahnken JD, et al. Cognitively impaired elderly exhibit insulin resistance and no memory improvement with infused insulin. Neurobiol Aging. 2016;39:19-24.

436

437

4. Fisher-Wellman KH, Neufer PD. Linking mitochondrial bioenergetics to insulin resistance via redox biology. Trends Endocrinol Metab. 2012.

5. Yuzefovych LV, Solodushko VA, Wilson GL, Rachek LI. Protection from palmitate-induced mitochondrial DNA damage prevents from mitochondrial oxidative stress, mitochondrial dysfunction, apoptosis, and impaired insulin signaling in rat $\mathrm{L} 6$ skeletal muscle cells. Endocrinology. 2012;153(1):92-100.

6. Lee HK, Kumar P, Fu Q, Rosen KM, Querfurth HW. The insulin/Akt signaling pathway is targeted by intracellular beta-amyloid. Mol Biol Cell. 2009;20(5):1533-1544.

7. Arvanitakis Z, Wilson RS, Bienias JL, Evans DA, Bennett DA. Diabetes mellitus and risk of Alzheimer disease and decline in cognitive function. Archives of neurology. 2004;61(5):661-666.

8. Cheng D, Noble J, Tang MX, Schupf N, Mayeux R, Luchsinger JA. Type 2 diabetes and late-onset Alzheimer's disease. Dement Geriatr Cogn Disord. 2011;31(6):424-430.

9. Janson J, Laedtke T, Parisi JE, O'Brien P, Petersen RC, Butler PC. Increased risk of type 2 diabetes in Alzheimer disease. Diabetes. 2004;53(2):474-481.

10. Leibson CL, Rocca WA, Hanson VA, et al. Risk of dementia among persons with diabetes mellitus: a population-based cohort study. American journal of epidemiology. 1997;145(4):301-308.

11. Luchsinger JA, Reitz C, Patel B, Tang MX, Manly JJ, Mayeux R. Relation of diabetes to mild cognitive impairment. Arch Neurol. 2007;64(4):570-575.

12. Ott A, Stolk RP, van Harskamp F, Pols HA, Hofman A, Breteler MM. Diabetes mellitus and the risk of dementia: The Rotterdam Study. Neurology. 1999;53(9):1937-1942.

13. Peila R, Rodriguez BL, Launer $\amalg$. Type 2 diabetes, APOE gene, and the risk for dementia and related pathologies: The Honolulu-Asia Aging Study. Diabetes. 2002;51(4):1256-1262.

14. Profenno LA, Porsteinsson AP, Faraone SV. Meta-analysis of Alzheimer's disease risk with obesity, diabetes, and related disorders. Biol Psychiatry. 2010;67(6):505-512.

15. Stewart R, Liolitsa D. Type 2 diabetes mellitus, cognitive impairment and dementia. Diabetic medicine : a journal of the British Diabetic Association. 1999;16(2):93-112.

16. van der Heide LP, Ramakers GM, Smidt MP. Insulin signaling in the central nervous system: learning to survive. Progress in neurobiology. 2006;79(4):205-221.

17. Xu W, Qiu C, Gatz M, Pedersen NL, Johansson B, Fratiglioni L. Mid- and late-life diabetes in relation to the risk of dementia: a population-based twin study. Diabetes. 2009;58(1):71-77.

18. Yaffe K, Blackwell T, Kanaya AM, Davidowitz N, Barrett-Connor E, Krueger K. Diabetes, impaired fasting glucose, and development of cognitive impairment in older women. Neurology. 2004;63(4):658-663.

19. Ott A, Stolk RP, van Harskamp F, Pols HAP, Hofman A, Breteler MMB. Diabetes mellitus and the risk of dementia: The Rotterdam Study. Neurology. 1999;53(9):1937.

20. Arvanitakis Z, Wilson RS, Bienias JL, Evans DA, Bennett DA. Diabetes Mellitus and Risk of Alzheimer Disease and Decline in Cognitive Function. Archives of Neurology. 2004;61(5):661666. 
medRxiv preprint doi: https://doi.org/10.1101/2020.07.20.20158022; this version posted July 25, 2020. The copyright holder for this preprint (which was not certified by peer review) is the author/funder, who has granted medRxiv a license to display the preprint in perpetuity.

All rights reserved. No reuse allowed without permission.

501

502

503

504

505

506

507

508

509

510

511

512

513

514

515

516

517

518

519

520

21. Janssen I, Heymsfield SB, Wang Z, Ross R. Skeletal muscle mass and distribution in 468 men and women aged 18-88 yr. In. Vol 892000:81-88.

22. Petersen RC, Aisen PS, Beckett LA, et al. Alzheimer's Disease Neuroimaging Initiative (ADNI): clinical characterization. Neurology. 2010;74(3):201-209.

23. Bailly M, Ribeiro MJ, Vercouillie J, et al. 18F-FDG and 18F-florbetapir PET in clinical practice: regional analysis in mild cognitive impairment and Alzheimer disease. Clin Nucl Med. 2015;40(2):e111-116.

24. Mosconi L. Brain glucose metabolism in the early and specific diagnosis of Alzheimer's disease. FDG-PET studies in MCI and AD. Eur J Nucl Med Mol Imaging. 2005;32(4):486-510.

25. Cavanna AE, Trimble MR. The precuneus: a review of its functional anatomy and behavioural correlates. Brain. 2006;129(Pt 3):564-583.

26. Gusnard DA, Raichle ME, Raichle ME. Searching for a baseline: functional imaging and the resting human brain. NatRevNeurosci. 2001;2(10):685-694.

27. Swerdlow RH, Koppel S, Weidling I, Hayley C, Ji Y, Wilkins HM. Mitochondria, Cybrids, Aging, and Alzheimer's Disease. Prog Mol Biol Transl Sci. 2017;146:259-302.

28. Silva DF, Selfridge JE, Lu J, et al. Bioenergetic flux, mitochondrial mass and mitochondrial morphology dynamics in AD and MCl cybrid cell lines. Hum Mol Genet. 2013;22(19):3931-3946.

29. Parker WD, Jr., Filley CM, Parks JK. Cytochrome oxidase deficiency in Alzheimer's disease. Neurology. 1990;40(8):1302-1303.

30. Chen HK, Ji ZS, Dodson SE, et al. Apolipoprotein E4 domain interaction mediates detrimental effects on mitochondria and is a potential therapeutic target for Alzheimer disease. The Journal of biological chemistry. 2011;286(7):5215-5221.

31. Oddo S, Caccamo A, Shepherd JD, et al. Triple-transgenic model of Alzheimer's disease with plaques and tangles: intracellular Abeta and synaptic dysfunction. Neuron. 2003;39(3):409-421.

32. Schuh RA, Jackson KC, Schlappal AE, et al. Mitochondrial oxygen consumption deficits in skeletal muscle isolated from an Alzheimer's disease-relevant murine model. BMC neuroscience. 2014;15:24.

33. Monteiro-Cardoso VF, Castro M, Oliveira MM, Moreira PI, Peixoto F, Videira RA. Age-dependent biochemical dysfunction in skeletal muscle of triple-transgenic mouse model of Alzheimer's disease. Current Alzheimer research. 2015;12(2):100-115.

34. Ye CY, Lei Y, Tang XC, Zhang HY. Donepezil attenuates Abeta-associated mitochondrial dysfunction and reduces mitochondrial Abeta accumulation in vivo and in vitro. Neuropharmacology. 2015;95:29-36.

35. Meunier J, leni J, Maurice T. The anti-amnesic and neuroprotective effects of donepezil against amyloid beta25-35 peptide-induced toxicity in mice involve an interaction with the sigma1 receptor. British journal of pharmacology. 2006;149(8):998-1012.

36. Maurice T, Meunier J, Feng B, leni J, Monaghan DT. Interaction with sigma(1) protein, but not Nmethyl-D-aspartate receptor, is involved in the pharmacological activity of donepezil. $J$ Pharmacol Exp Ther. 2006;317(2):606-614.

37. Area-Gomez E, de Groof A, Bonilla E, et al. A key role for MAM in mediating mitochondrial dysfunction in Alzheimer disease. Cell Death Dis. 2018;9(3):335.

38. Kim E, Park M, Jeong J, et al. Cholinesterase Inhibitor Donepezil Increases Mitochondrial Biogenesis through AMP-Activated Protein Kinase in the Hippocampus. Neuropsychobiology. 2016;73(2):81-91.

39. Lu J, E L, Roy N, et al. Effect of cholinergic signaling on neuronal cell bioenergetics. Journal of Alzheimer's disease : JAD. 2013;33(4):1135-1146. 
medRxiv preprint doi: https://doi.org/10.1101/2020.07.20.20158022; this version posted July 25, 2020. The copyright holder for this preprint (which was not certified by peer review) is the author/funder, who has granted medRxiv a license to display the preprint in perpetuity.

All rights reserved. No reuse allowed without permission.

521 40. Liu X, Xu K, Yan M, Wang Y, Zheng X. Protective effects of galantamine against Abeta-induced PC12 cell apoptosis by preventing mitochondrial dysfunction and endoplasmic reticulum stress. Neurochemistry international. 2010;57(5):588-599.

41. McAllister J, Ghosh S, Berry D, et al. Effects of memantine on mitochondrial function. Biochem Pharmacol. 2008;75(4):956-964.

42. Hirano K, Fujimaki M, Sasazawa Y, et al. Neuroprotective effects of memantine via enhancement of autophagy. Biochem Biophys Res Commun. 2019;518(1):161-170.

43. Hampel $\mathrm{H}$, Mesulam MM, Cuello AC, et al. The cholinergic system in the pathophysiology and treatment of Alzheimer's disease. Brain. 2018;141(7):1917-1933.

44. Jacobson SA, Sabbagh MN. Donepezil: potential neuroprotective and disease-modifying effects. Expert opinion on drug metabolism \& toxicology. 2008;4(10):1363-1369.

45. Kim SH, Kandiah N, Hsu JL, Suthisisang C, Udommongkol C, Dash A. Beyond symptomatic effects: potential of donepezil as a neuroprotective agent and disease modifier in Alzheimer's disease. British journal of pharmacology. 2017;174(23):4224-4232.

46. Hashimoto M, Kazui H, Matsumoto K, Nakano Y, Yasuda M, Mori E. Does donepezil treatment slow the progression of hippocampal atrophy in patients with Alzheimer's disease? Am J Psychiatry. 2005;162(4):676-682.

47. Blanco-Silvente L, Castells X, Saez M, et al. Discontinuation, Efficacy, and Safety of Cholinesterase Inhibitors for Alzheimer's Disease: a Meta-Analysis and Meta-Regression of 43 Randomized Clinical Trials Enrolling 16106 Patients. The international journal of neuropsychopharmacology. 2017;20(7):519-528.

48. Atukeren $\mathrm{P}$, Cengiz $\mathrm{M}$, Yavuzer $\mathrm{H}$, et al. The efficacy of donepezil administration on acetylcholinesterase activity and altered redox homeostasis in Alzheimer's disease. Biomedicine \& pharmacotherapy = Biomedecine \& pharmacotherapie. 2017;90:786-795.

49. Casademont J, Miro O, Rodriguez-Santiago B, Viedma P, Blesa R, Cardellach F. Cholinesterase inhibitor rivastigmine enhance the mitochondrial electron transport chain in lymphocytes of patients with Alzheimer's disease. Journal of the neurological sciences. 2003;206(1):23-26.

50. Jastroch M, Divakaruni AS, Mookerjee S, Treberg JR, Brand MD. Mitochondrial proton and electron leaks. Essays Biochem. 2010;47:53-67.

51. ACSM ACOSM. ACSM's guidelines for exercise testing and prescription. 8th ed. Philladelphia: Lippincott Williams \& Wilkins; 2010.

52. Coen PM, Jubrias SA, Distefano G, et al. Skeletal muscle mitochondrial energetics are associated with maximal aerobic capacity and walking speed in older adults. J Gerontol A Biol Sci Med Sci. 2013;68(4):447-455.

53. Karakelides H, Irving BA, Short KR, O'Brien P, Nair KS. Age, obesity, and sex effects on insulin sensitivity and skeletal muscle mitochondrial function. Diabetes. 2010;59(1):89-97.

54. Costill DL, Daniels J, Evans W, Fink W, Krahenbuhl G, Saltin B. Skeletal muscle enzymes and fiber composition in male and female track athletes. J Appl Physiol. 1976;40(2):149-154.

55. Valla J, Schneider L, Niedzielko T, et al. Impaired platelet mitochondrial activity in Alzheimer's disease and mild cognitive impairment. Mitochondrion. 2006;6(6):323-330.

56. Holper L, Ben-Shachar D, Mann JJ. Multivariate meta-analyses of mitochondrial complex I and IV in major depressive disorder, bipolar disorder, schizophrenia, Alzheimer disease, and Parkinson disease. Neuropsychopharmacology. 2019;44(5):837-849.

57. Vidoni ED, Bothwell RJ, Burns JM, Dwyer JR. Novel recruitment models will drive Alzheimer's trial success. Alzheimers Dement. 2018;14(1):117-119.

58. Billinger SA, Vidoni ED, Greer CS, Graves RS, Mattlage AE, Burns JM. Cardiopulmonary exercise testing is well tolerated in people with Alzheimer-related cognitive impairment. Arch Phys Med Rehabil. 2014;95(9):1714-1718. 
medRxiv preprint doi: https://doi.org/10.1101/2020.07.20.20158022; this version posted July 25, 2020. The copyright holder for this preprint (which was not certified by peer review) is the author/funder, who has granted medRxiv a license to display the preprint in perpetuity. All rights reserved. No reuse allowed without permission.

59. Morris JK, Vidoni ED, Johnson DK, et al. Aerobic exercise for Alzheimer's disease: A randomized

572

573

574

575 controlled pilot trial. PloS one. 2017;12(2):e0170547.

60. Billinger SA, Vidoni ED, Honea RA, Burns JM. Cardiorespiratory response to exercise testing in individuals with Alzheimer's disease. Arch Phys Med Rehabil. 2011;92(12):2000-2005.

61. Vidoni ED, Johnson DK, Morris JK, et al. Dose-Response of Aerobic Exercise on Cognition: A Community-Based, Pilot Randomized Controlled Trial. PloS one. 2015;10(7):e0131647.

62. Choi L, Liu Z, Matthews CE, Buchowski MS. Validation of accelerometer wear and nonwear time classification algorithm. Medicine and science in sports and exercise. 2011;43(2):357-364. 
579 Figure 1. Skeletal muscle mitochondrial respiration differs between groups.

580

A.

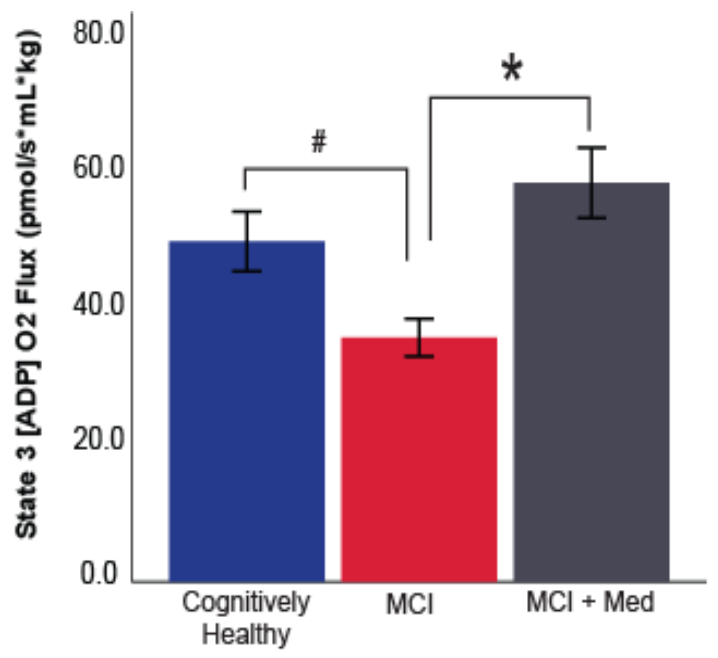

B.

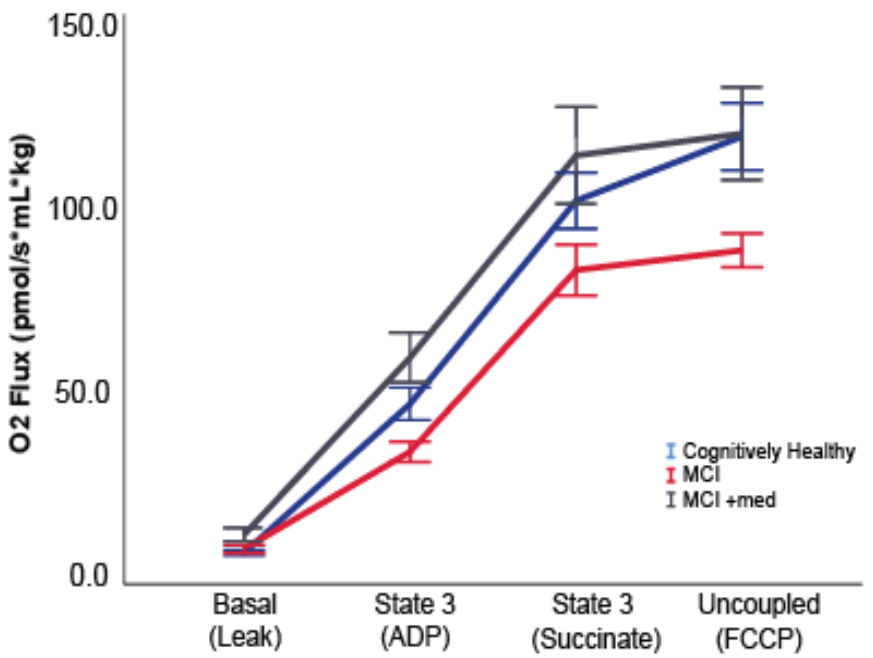

Figure 1. Lipid (palmitoylcarnitine) stimulated skeletal muscle mitochondrial respiration was

584 lower in $\mathrm{MCl}$ subjects during State $3(\mathrm{ADP})$ compared to both other groups (A). Responses were also assessed under a sequence of conditions, and the overall group response differed across the states $(p<0.001)$. Ordinary least squares regression was used for State 3 univariate

587 analyses. The repeated measures overall responses to substrate conditions was assessed 588 using linear mixed modeling. Both sets of analyses adjusted for covariates. \#p<0.05 MCI no 589 drug vs. $\mathrm{CH} .{ }^{*} \mathrm{p}<0.05 \mathrm{MCl}$ vs. $\mathrm{MCl}+$ med. $\mathrm{CH} n=24, \mathrm{MCl} n=11, \mathrm{MCl}+$ med $\mathrm{n}=15$ subjects per 590 group. 
medRxiv preprint doi: https://doi.org/10.1101/2020.07.20.20158022; this version posted July 25, 2020. The copyright holder for this preprint (which was not certified by peer review) is the author/funder, who has granted medRxiv a license to display the preprint in perpetuity.

All rights reserved. No reuse allowed without permission.

592 Figure 2. Diagnostic differences in mitochondrial control ratios.

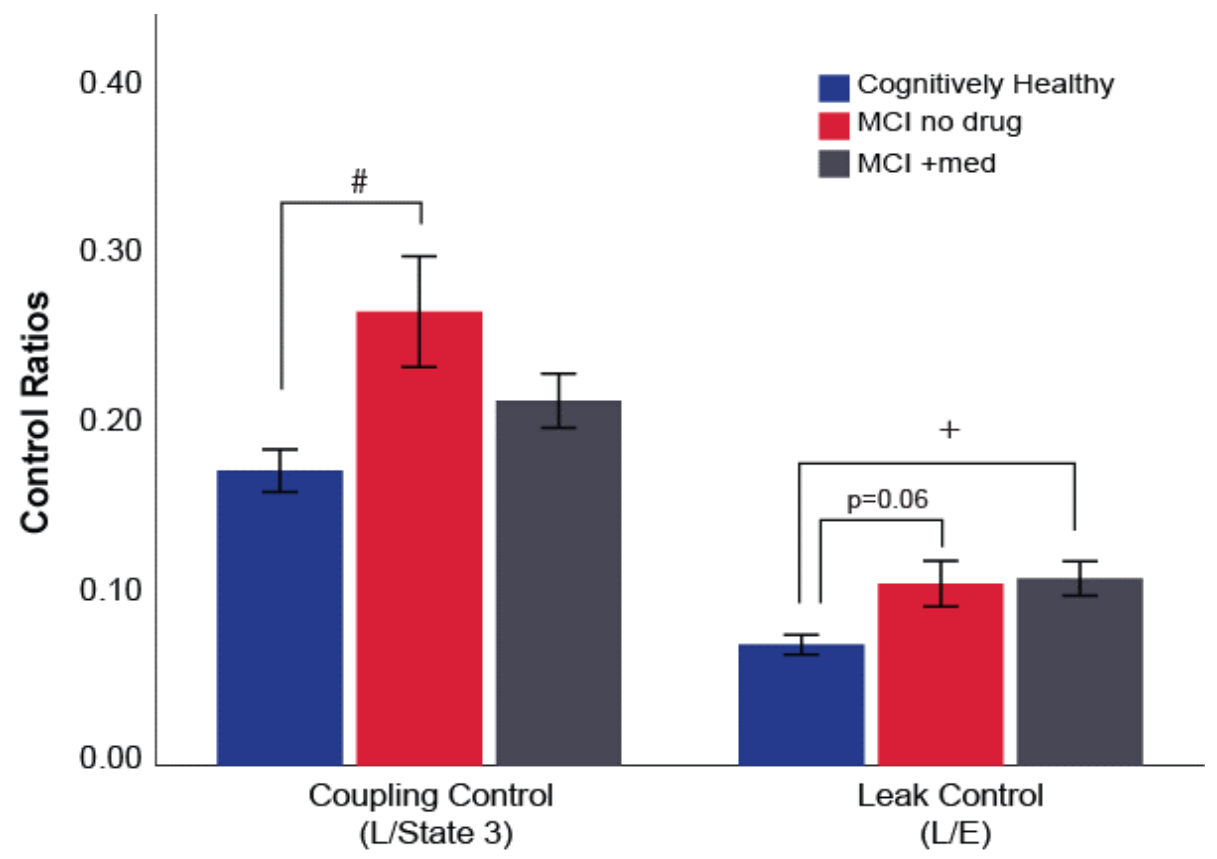

594 Figure 2. $\mathrm{MCl}$ subjects not treated with mediation exhibited poorer coupling control (higher

595 control ratio) compared to $\mathrm{CH}$ subjects. Both $\mathrm{MCl}$ groups exhibited poorer leak control

596 compared to $\mathrm{CH}$ individuals. Group differences were assessed using ANCOVA, adjusting for

597 covariates. $\# p<0.05 \mathrm{CH}$ vs $\mathrm{MCl},+\mathrm{p}<0.05 \mathrm{CH}$ vs. $\mathrm{MCl}+$ med. $\mathrm{CH} \mathrm{n}=24, \mathrm{MCl} \mathrm{n}=11, \mathrm{MCl}+$ med

$598 \quad n=15$ subjects per group.

599

600 


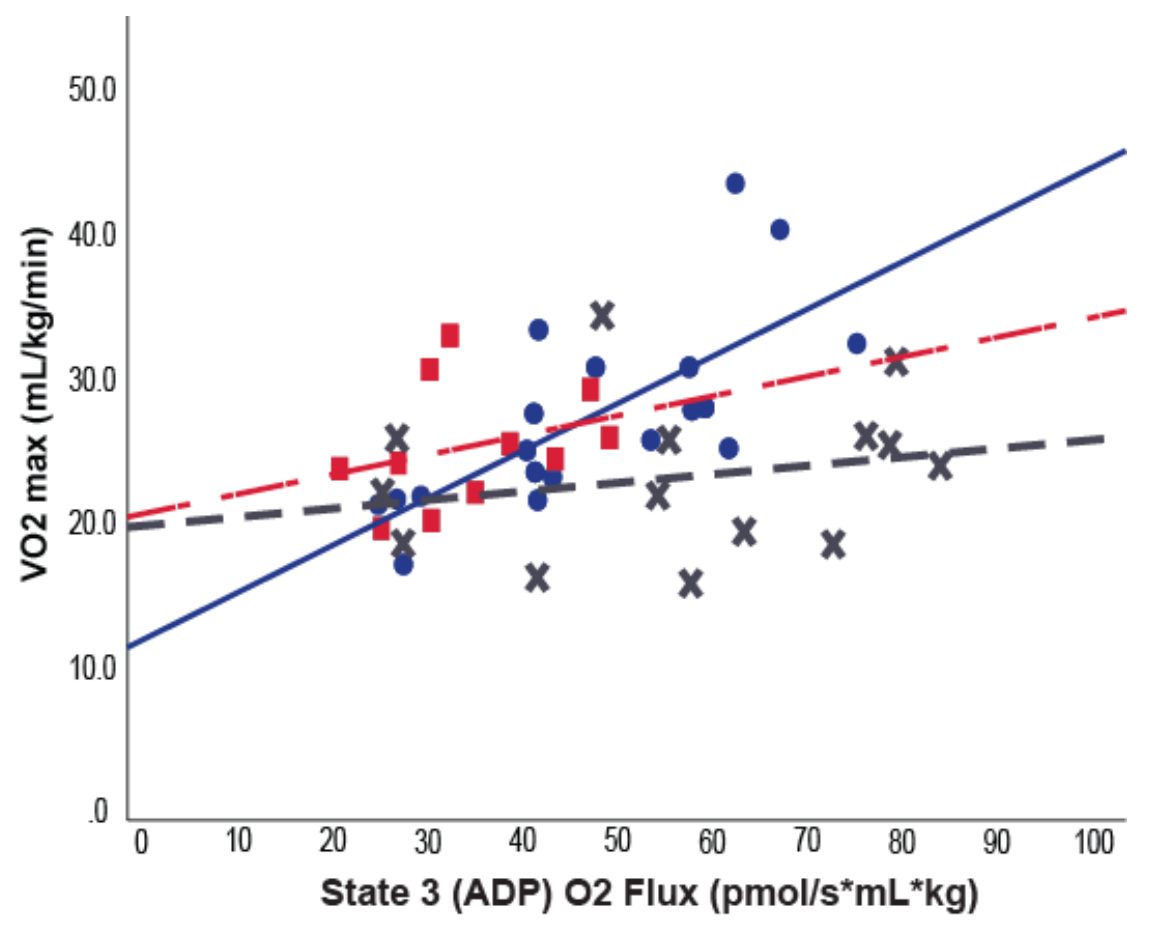

603

Figure 3. In $\mathrm{CH}$ (solid blue line) and $\mathrm{MCl}$ (dashed red line) individuals who met established

605 criteria for a reliable graded exercise test $(n=44)$, cardiorespiratory fitness tracks with State 3

606 (ADP) respiration $(\mathrm{CH} ; \beta=0.615, \mathrm{p}=0.024$ and $\mathrm{MCl} ; \beta=0.615, \mathrm{p}=0.036)$. There is no significant

607 relationship in medication-treated $\mathrm{MCl}$ subjects (dashed gray line). Relationships were

608 assessed within each group using linear regression, adjusting for covariates. $\mathrm{CH} n=19, \mathrm{MCl}$

$609 \mathrm{n}=11, \mathrm{MCl}+$ med $\mathrm{n}=14$ subjects per group.

610

611 
613 Figure 4. Skeletal muscle protein expression of mitochondrial complexes.
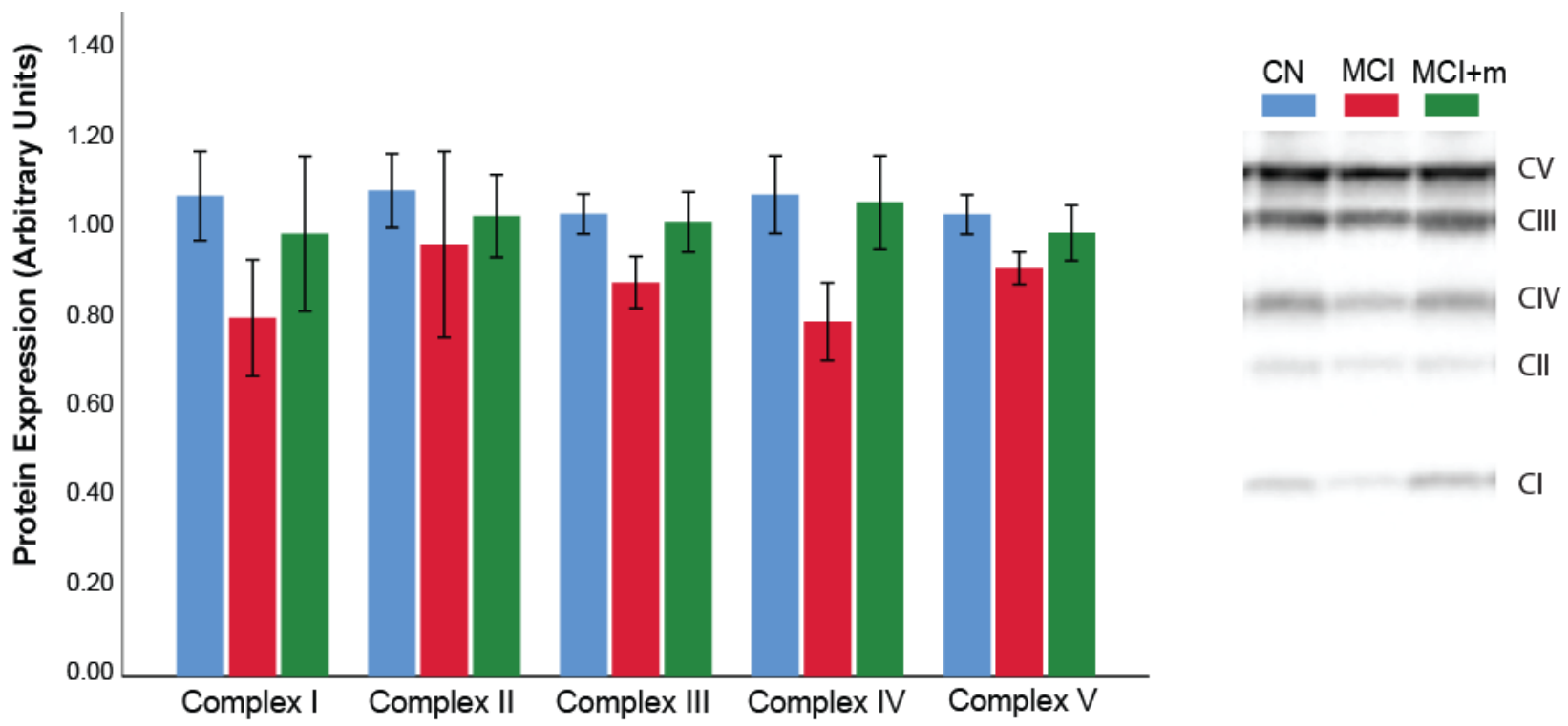

617 Figure 4. Untreated $\mathrm{MCl}$ individuals exhibited a consistent but nonsignificant trend for lower

618 protein expression of mitochondrial complex proteins in skeletal muscle. Group differences were 619 assessed using ANCOVA, adjusting for covariates. These analyses were performed on a subset 620 of individuals $(n=44)$ for whom sufficient muscle sample was available $(\mathrm{CH} n=21, \mathrm{MCI} n=10$, $621 \mathrm{MCl}+$ med $\mathrm{n}=14)$. 
medRxiv preprint doi: https://doi.org/10.1101/2020.07.20.20158022; this version posted July 25, 2020. The copyright holder for this preprint (which was not certified by peer review) is the author/funder, who has granted medRxiv a license to display the preprint in perpetuity.

624 Table 1. Subject Characteristics

\begin{tabular}{|c|c|c|c|c|}
\hline Outcome & $\mathrm{CH}(\mathrm{n}=24)$ & $\operatorname{MCl}(n=11)$ & $\mathrm{MCl}+\operatorname{Med}(\mathrm{n}=15)$ & p-value \\
\hline Age (y) & $72.5[8.5]$ & $69.6[7.4]$ & 74.9 [7.3] & 0.253 \\
\hline Sex (\#, \% female) & $12[48 \%]$ & 9 [82\%] & $7(47 \%]$ & 0.128 \\
\hline APOE4 (\#, \% carrier) & 9 [36\%] & $8[73 \%]$ & $7[47 \%]$ & 0.126 \\
\hline Education (y) & $16.9[1.7]$ & 16.9 [2.3] & 15.8 [2.3] & 0.250 \\
\hline Overweight/Obesity (\#,\%) & $15[62 \%]$ & 3 [27\%] & 9 [60\%] & 0.130 \\
\hline Activity per day (counts) & 12689.8 [3470] & 14936 [3242] & $10121.0[3014]$ & $0.010^{\star,+}$ \\
\hline $\mathrm{VO}_{2 \text { peak }}(\mathrm{mL} / \mathrm{kg} / \mathrm{min})$ & $26.5[6.9]$ & $25.8[4.2]$ & $22.8[6.7]$ & 0.155 \\
\hline GXT duration (min) & $13.1[2.6]$ & $12.4[2.5]$ & $9.51[3.3]$ & $<0.001^{*,+}$ \\
\hline Resting RER & $0.831[0.08]$ & $0.773[0.04]$ & $0.780[0.08]$ & $0.031^{\#,+}$ \\
\hline Peak HR & $159.8[20.1]$ & $154.9[15.0]$ & $148.7[27.4]$ & 0.437 \\
\hline BMD & $1.25[0.19]$ & $1.11[0.16]$ & $1.20[0.13]$ & 0.228 \\
\hline Waist Hip Ratio & $0.883[0.12]$ & $0.814[0.08]$ & $0.917[0.11]$ & 0.276 \\
\hline Lean mass (kg) & $47.5[10.7]$ & $37.9[10.6]$ & $48.3[10.4]$ & 0.100 \\
\hline Fat mass (kg) & $27.0[9.3]$ & $19.5[5.1]$ & 29.9 [11.2] & $0.027^{+}$ \\
\hline
\end{tabular}

626 Table 1. Subject characteristics. Values are given as means [SD]. $\mathrm{p}<0.05{ }^{\#} \mathrm{CH}$ vs $\mathrm{MCl},{ }^{+} \mathrm{CH}$ vs

$627 \mathrm{MCl}+$ med, "MCl vs $\mathrm{MCl}+$ med. APOE; Apolipoprotein E, BMl; body mass index, GXT; graded 628 exercise test, RER; respiratory exchange ratio, HR; heart rate. 
Table 2. Metabolic biomarkers

\begin{tabular}{|l|l|l|l|l|}
\hline Outcome & CH (n=24) & MCI (n=11) & $\mathbf{M C l}+$ Med (n=15) & p-value \\
\hline Glucose (mg/dL) & $90.3[9.0]$ & $93.3[12.6]$ & $97.5[10.9]$ & 0.181 \\
\hline Insulin (uU/mL) & $13.4[30.8]$ & $18.0[44.3]$ & $10.3[11.6]$ & 0.830 \\
\hline Cholesterol (mg/dL) & $186.5[41.7]$ & $190.1[38.1]$ & $186.5[53.6]$ & 0.991 \\
\hline Triglycerides (mg/dL) & $97.0[53.2]$ & $85.9[26.7]$ & $98.0[51.0]$ & 0.770 \\
\hline HDL (mg/dL) & $64.8[19.4]$ & $73.2[15.6]$ & $59.5[12.8]$ & 0.663 \\
\hline LDL (mg/dL) & $102.4[35.0]$ & $99.8[35.0]$ & $104.7[46.8]$ & 0.792 \\
\hline LDL/HDL (mg/dL) & $1.63[0.52]$ & $1.42[0.66]$ & $1.77[0.80]$ & 0.747 \\
\hline HOMA-IR (mg/dL) & $3.02[6.9]$ & $4.37[10.9]$ & $2.55[3.0]$ & 0.813 \\
\hline
\end{tabular}

632 Table 2. Fasting serum biomarker levels do not differ amongst groups. Values are given as means [SD]. HDL; high density lipoprotein, LDL; low density lipoprotein; HOMA-IR; homeostasis model assessment of insulin resistance. 